Article

\title{
Bacterial Biodegradation of 4-Monohalogenated Diphenyl Ethers in One-Substrate and Co-Metabolic Systems
}

\author{
Amanda Pacholak $^{1}{ }^{\circledR}$, Wojciech Smułek ${ }^{1, * \mathbb{C}}$, Agata Zdarta ${ }^{1}{ }^{\circledR}$, Agnieszka Zgoła-Grześkowiak ${ }^{2}$ \\ and Ewa Kaczorek ${ }^{1}$ (D) \\ 1 Institute of Chemical Technology and Engineering, Poznan University of Technology, Berdychowo 4, \\ 60-965 Poznan, Poland; amanda.d.pacholak@doctorate.put.poznan.pl (A.P.); \\ agata.zdarta@doctorate.put.poznan.pl (A.Z.); ewa.kaczorek@put.poznan.pl (E.K.) \\ 2 Institute of Chemistry and Technical Electrochemistry, Poznan University of Technology, Berdychowo 4, \\ 60-965 Poznan Poland; agnieszka.zgola-grzeskowiak@put.poznan.pl \\ * $\quad$ Correspondence: wojciech.smulek@put.poznan.pl; Tel.: +48-61-665-3688
}

Received: 28 August 2018; Accepted: 12 October 2018; Published: 19 October 2018

\begin{abstract}
The use of diphenyl ether (DE) and its 4-monohalogenated derivatives (4-HDE) as flame retardants, solvents, and substrates in biocide production significantly increases the risk of ecosystem contamination. Their removal is important from the point of view of environmental protection. The aim of this study was to evaluate the degradation processes of DE and 4-HDE by enzymes of the environmental bacterial strains under one-substrate and co-metabolic conditions. The study is focused on the biodegradation of DE and 4-HDE, the enzymatic activity of microbial strains, and the cell surface properties after contact with compounds. The results show that the highest biodegradation (96\%) was observed for 4-chlorodiphenyl ether in co-metabolic culture with P. fluorescens B01. Moreover, the activity of 1,2-dioxygenase during degradation of 4-monohalogenated diphenyl ethers was higher than that of 2,3-dioxygenase for each strain tested. The presence of a co-substrate provoked changes in dioxygenase activity, resulting in the increased activity of 1,2-dioxygenase. Moreover, the addition of phenol as a co-substrate allowed for increased biodegradation of the diphenyl ethers and noticeable modification of the cell surface hydrophobicity during the process. All observations within the study performed have led to a deeper understanding of the contaminants' biodegradation processes catalyzed by environmental bacteria.
\end{abstract}

Keywords: diphenyl ether; co-metabolism; phenol; biodegradation; biocatalysts

\section{Introduction}

Diphenyl ether and its chlorinated and brominated derivatives have found many industrial applications [1]. They are applied in the synthesis of pesticides, disinfectants, and other biocides. Moreover, brominated diphenyl ethers (BDE) are used as flame retardants in paints, lacquers, composites, and textiles [2]. Chlorinated diphenyl ethers (CDE) act as industrial fluids and biocides [3]. BDE and CDE belong to the chemically passive compounds, showing resistance to acids and bases. They are also poorly soluble in water, but have a high affinity to fats, which facilitates their accumulation in the tissues of living organisms [4].

The high toxicity of BDE and CDE, intensified by their bioaccumulation [5], has been confirmed by laboratory studies, which indicate that long-term exposure to BDE and CDE may cause enlargement of some internal organs of mammals, as well as disturb their hormonal balance [2]. The observed effects on changes in genetic material may also confirm that these compounds are carcinogenic [6]. 
Large-scale production of these compounds and their various and widespread use means that the contamination of the natural environment with them is high $[7,8]$.

The effectiveness of the biodegradation of organic compounds depends significantly on the availability of oxygen in the environment [9]. In soil and water ecosystems, biodegradation is frequently conducted by both aerobic and anaerobic microorganisms [10]. Aerobic bacteria biodegrade these compounds by cleavage of the aromatic ring, which leads to the creation of a relatively small number of intermediates and final products. In turn, anaerobic bacteria only slightly dehalogenate and reduce the number of halogen atoms in the biodegradable molecule. What is more, they also carry out the breakdown of the aromatic ring more slowly [11-13]. For this reason, it is advisable to use, if possible, aerobic bacteria for the efficient removal of halogen derivatives of diphenyl ether from the environment. Previous studies indicated that effective biodegradation of brominated diphenyl ether derivatives may be carried out by environmental bacterial strains such as Sphingomonas sp. Ss3, Sphingomonas sp. PH-07, Pseudomonas cepacia, and Erwinia sp. [2].

Industrial waste very often contains different groups of contaminants, which leads to co-metabolic biodegradation [14]. The presence of a co-metabolite may promote increased activity of enzymes involved in biodegradation, especially if all biodegradable compounds are degraded using analogous metabolic pathways [15]. In addition, an easier accessible carbon source can contribute to the additional multiplication of microorganisms, so that more of them can participate in the persistent pollutants' biodegradation [16]. The beneficial effect of co-metabolism has been observed in the biodegradation of xylenes [17], atrazine [18], and several pharmaceuticals [19].

However, it should be taken into account that the presence of additional compounds in the environment may have a negative effect on a given biodegradation process [20]. The first threat is that the metabolic pathways of cells could be switched to the biodegradation of a relatively more readily available and less toxic carbon source, while the biodegradation of the compound of higher toxicity would be stopped or significantly reduced [21]. The second mechanism leading to the reduction of biodegradation efficiency is the inhibition of metabolic pathways caused by the presence of an accompanying chemical compound or one of its breakdown products. As a result, the biodegradation of a more toxic compound is blocked or severely slowed down [22].

Therefore, biodegradation in the conditions of co-metabolism is an important aspect of the degradation of persistent and toxic organic pollutants [17]. Unfortunately, there is practically no information in the literature about the co-metabolic biodegradation of halogen derivatives of diphenyl ethers. In view of the high toxicity of this group of chemical compounds and their widespread use, it is highly desirable to develop effective strategies for their biodegradation by finding bacterial strains capable of using them as a source of carbon and energy as well as by indicating co-substrates that will increase the biodegradation of halogenated diphenyl ether derivatives.

Therefore, the present study was aimed at the identification of environmental bacteria strains degrading 4-monohalogenated diphenyl ethers and an analysis of the impact of co-metabolites on the biodegradation process. The quantitative analysis of the degraded compounds in the cultures was supported by enzyme activity measurements. Apart from the biodegradation tests, the cell surface properties representing changes in cell modifications during pollutant degradation were also studied. The present study brings a new perspective on the biodegradation of 4-monohalogenated diphenyl ethers in the context of co-metabolism and cell surface properties during the process.

\section{Results}

\subsection{Biodegradation of (4-Monohalogenated) Diphenyl Ethers}

Biodegradation of diphenyl ether (DE) and its 4-monohalogenated derivatives (4-bromodiphenyl ether-BDE; 4-chlorodiphenyl ether- $\mathrm{CDE}$ ) was monitored in one-substrate and co-metabolic systems on a laboratory scale. Phenol (Ph) was applied as a co-metabolic substrate. The content of residual 
amounts of compounds degraded was analyzed after seven and 14 days of cultivation using the GC/MS method for ethers and HPLC/FD for phenol.

Figure 1 shows the results obtained for the biodegradation tests of diphenyl ethers by Pseudomonas fluorescens B01 (Figure 1a,b) and Pseudomonas plecoglossicida IsA (Figure 1c,d). From all the tested samples, the highest removal level (96\%) was observed for CDE in co-metabolic culture with P. fluorescens B01 after 14 days (Figure 1b); the lowest biodegradation level (12\%) was noted in the sample containing DE and P. plecoglossicida IsA strain (Figure 1c). A major increase in biodegradation in the presence of phenol (from 38\% to 64\%) was observed for BDE in the seven-day culture (Figure 1a). Moreover, the removal of DE by P. fluorescens B01 was 45\% in one-substrate culture after 14 days of cultivation, while that of BDE and CDE reached $70 \%$ in parallel systems (Figure $1 \mathrm{~b}$ ). In addition, the presence of phenol in bacterial cultures caused an increase in biodegradation of BDE and CDE to $88 \%$ and $96 \%$, respectively, after 14 days. Such relationships were not observed for degradation of $\mathrm{DE}$, in which the co-metabolism did not increase the level of biodegradation. For P. plecoglossicida IsA strain, the highest impact of the phenol addition to microbial culture on diphenyl ethers removal was observed for BDE (Figure 1c). Its removal efficiency increased from $20 \%$ to $60 \%$ in a seven-day sample containing phenol as a co-substrate. It should be emphasized that 4-monohalogenated diphenyl ethers were more biodegradable than their unsubstituted equivalent. In addition, P. plecoglossicida IsA showed lower ability than P. fluorescens B01 to degrade all the compounds studied. Phenol, in general, was degraded in significantly smaller amounts than ethers; its biodegradation did not exceed $47 \%$ for P. fluorescens B01 and 34\% for P. plecoglossicida IsA. Importantly, the highest degradation efficiency was observed in microbial systems that contained Ph and DE as sources of carbon and energy for both strains. In contrast, Mamma et al. [23], Bakhshi et al. [24], and Perpetuo et al. [25] have reported the efficient degradation of phenol in biological systems. The incomplete degradation of phenol in our studies could be explained by the changed metabolism of microorganisms towards ethers.

It should be noted that, according to the chemical stability, an ether group is not readily degradable in biological systems [26]. However, several authors have reported the biodegradation of diphenyl ether and polybrominated diphenyl ethers. For example, Kim et al. [26] have shown that Sphingomonas sp. PH-07 degraded $1 \mathrm{~g} \mathrm{~L}^{-1}$ of diphenyl ether within six days. Moreover, Stenotrophomonas sp. strain WZN-1 has been shown to be able to degrade $55 \%$ of $65 \mu \mathrm{g} \mathrm{L}{ }^{-1}$ decabromodiphenyl ether under one-substrate aerobic conditions in a 30-d culture [27]. In accordance with the present results, previous studies by Heidari et al. [28] have demonstrated that the presence of phenol as a growth substrate in microbial culture has contributed to the increased biodegradation of aromatic organic compound bisphenol A from $10 \%$ to $50 \%$. Furthermore, in the present study chlorinated diphenyl ether was more degradable than brominated, under both one-substrate and co-metabolic conditions. In contrast, it has been reported that Sphingomonas sp. SS3 strain can effectively biodegrade only 4-chlorodiphenyl ether under co-metabolic conditions [29].

The results of this study have proven that both strains have the potential to grow on diphenyl ether, 4-chloro- and 4-bromodiphenyl ether and co-metabolically degrade these compounds, either as single compounds or in a mixture with phenol. 


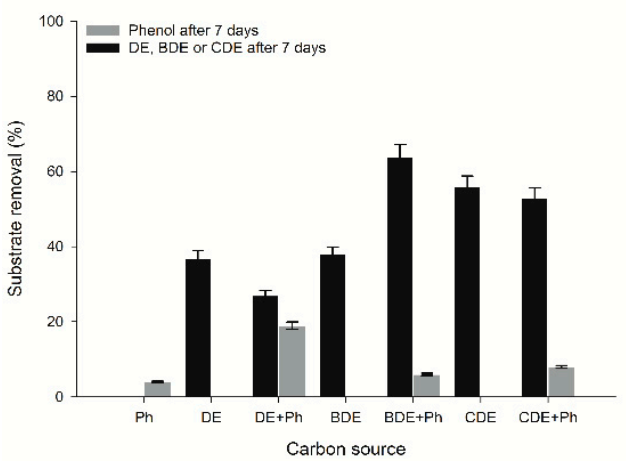

(a)

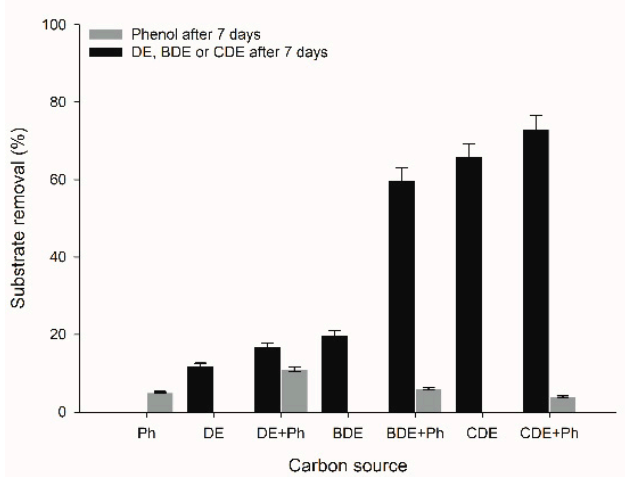

(c)

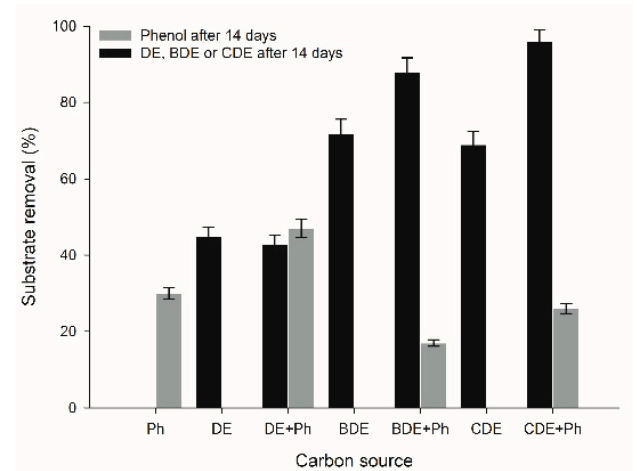

(b)

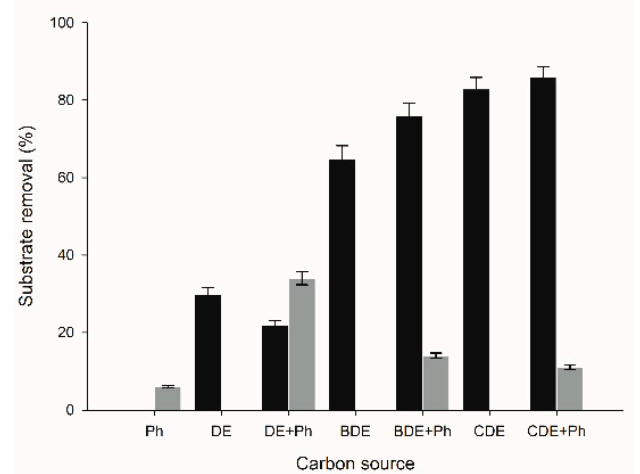

(d)

Figure 1. Levels of removal of phenol as a sole carbon source and in co-metabolism (examined by HPLC/FD analysis) and diphenyl ether and its derivatives as sole carbon sources and in co-metabolism (examined by GC/MC analysis) measured in cultures of (a) P. fluorescens B01 after seven days; (b) P. fluorescens B01 after 14 days; (c) P. plecoglossicida IsA after seven days and (d) P. plecoglossicida IsA after 14 days. Letters on the x-axis refer to different carbon sources: $\mathrm{Ph}$-phenol; DE-diphenyl ether; BDE-4-bromodiphenyl ether; CDE-4-chlorodiphenyl ether. All measurements were made in triplicate and the values are presented as a mean \pm standard deviation.

\subsection{Cell Metabolic Activity}

The next stage of the research was devoted to an analysis of the changes in the cell metabolic activity during the biodegradation of selected aromatic compounds. The MTT assay, used mainly for measurements of metabolic activity of eukaryotic cells, was also applied in bacteria research $[30,31]$. The assay in question is based on the reduction of a yellow, water-soluble MTT reagent (3-(4,5-dimethylthiazol2-yl)-2,5-diphenyl-trazolium bromide) into its purple formazan salt, but only by metabolically active cells. The assay performed allowed us to investigate the total microbial metabolic activity during the biodegradation of 4-monohalogenated diphenyl ethers.

The results obtained show that among the tested compounds phenol $(\mathrm{Ph})$ and diphenyl ether (DE) exhibit the greatest inhibiting effect on the metabolism of P. plecoglossicida IsA cells (Figure 2a), especially in 14-day cultures. In these samples the relative cell metabolic activity did not exceed 30\% after seven days and $20 \%$ after 14 days. The highest metabolic activity (over $90 \%$ ) after one week was observed for the cultures with 4-bromodiphenyl ether. From among the cultures with diphenyl ether and its derivatives as the sole carbon source, the lowest metabolic activity ( $30 \%$ after one week) was observed for diethyl ether. 


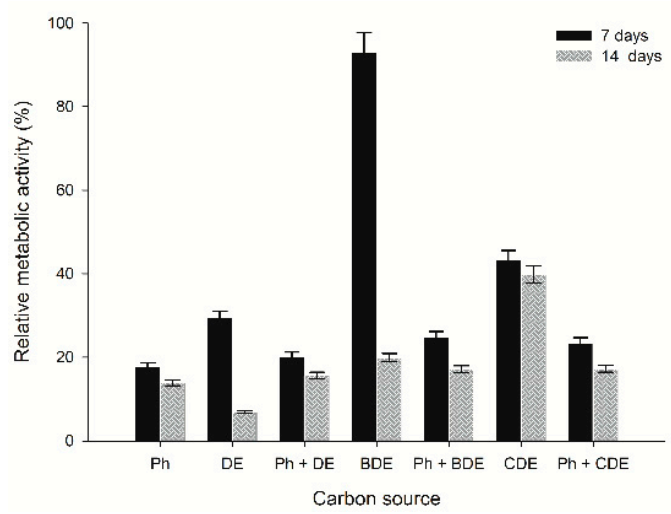

(a)

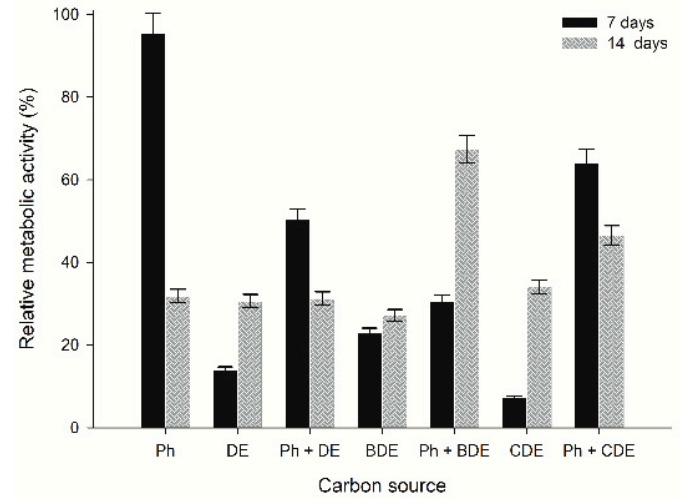

(b)

Figure 2. Changes in relative cell metabolic activity during biodegradation of phenol (Ph), diphenyl ether (DE), 4-bromodiphenyl ether (BDE), 4-chlorodiethylether (CDE) and their mixtures by (a) P. plecoglossicida IsA and (b) P. fluorescens B01.

The results obtained for the second strain were significantly different, as presented in Figure $2 \mathrm{~b}$. The cells of $P$. fluorescens B01 had relatively high metabolic activity when phenol was biodegraded, especially when it was the sole carbon and energy source. Then, cell metabolic activity reached nearly $100 \%$ after seven days. However, within 14 days this value decreased to $32 \%$. Worth noting are the results obtained for the cultures with diethyl ether and its 4-monohalogenated derivatives. The metabolic activity in the 14-day culture was higher than that in the seven-day culture. This can be explained by a longer adaptation period of P. fluorescens B01 cells adaptation to the degradation of these compounds. Additionally, an analogous phenomenon may take place in the phenol and 4-bromodiphenyl ether co-metabolism.

The metabolic activity measured by activity assays of a wide group of enzymes revealed significant changes in this parameter over time during the bioremediation of xenobiotics. $\mathrm{Xu}$ et al. [32] have investigated the level of cell dehydrogenase activity during the biodegradation of PAH (polycyclic aromatic hydrocarbons)-contaminated soil and observed an increase in activity, even in control samples that were not supplemented with additional bacterial strains. The PAH biodegradation and accompanying bacteria metabolic activity changes have also been the subject of a study of Scelza et al. [33]. The study reported in [34] has also shown remarkable changes in dehydrogenase activity of microbial consortium degrading crude oil. In the samples without any additional nutrient, the activity increased during the first four weeks and then a significant decrease was observed. It should be noted that in the research mentioned, the monitoring of the cell metabolic activity has been applied for the complex consortium but not for single strain cultures. However, the results described above show that the analysis of one-strain cultures can also bring additional information about the kinetics of aromatic compounds' biodegradation.

\subsection{Enzymatic Activity}

In parallel to biodegradation studies, measurements of enzymatic activity of the two tested strains was performed. The levels of catechol 1,2-dioxygenase and 2,3-dioxygenase activity were evaluated after contact with diphenyl ether (DE), 4-bromodiphenyl ether (BDE), and 4-chlorodiphenyl ether (CDE) under one-substrate and co-metabolic conditions. In the co-metabolic cultures, phenol was used as an additional source of carbon. The control samples included the one with sodium succinate as the only source of carbon and energy as well as the culture that contained phenol as the source of carbon and energy.

Table 1 presents the results of enzymatic activity of P. plecoglossicida IsA and P. fluorescens B01. From the two tested enzymes, 1,2-dioxygenase was characterized by higher activity in each strain tested. For P. plecoglossicida IsA, the highest enzymatic activity $\left(339.27 \pm 16.96 \mathrm{mU} \mathrm{mg}^{-1}\right)$ was noted 
in the sample containing BDE and phenol. However, the lowest activity of 1,2-dioxygenase for P. plecoglossicida IsA was observed in the culture with CDE. The results referring to the 2,3-dioxygenase activity were different. This enzyme showed the highest activity in the sample with sodium succinate $\left(268.63 \pm 13.43 \mathrm{mU} \mathrm{mg}^{-1}\right)$ and the lowest in the samples containing DE $+\mathrm{Ph}, \mathrm{CDE}$ and CDE $+\mathrm{Ph}$ $\left(<0.1 \mathrm{mU} \mathrm{mg}^{-1}\right)$. It should be highlighted that for the P. plecoglossicida IsA strain we observed an increase in the activity of dioxygenases from the microbial cells grown in the co-metabolic conditions relative to that of dioxygenase from the cells grown in the one-substrate condition in the cultures with 4-monohalogenated diphenyl ethers. However, in the cultures with non-substituted diphenyl ether a decrease in dioxygenase activity was noticed.

Table 1. Results of relative enzymatic activity of P. plecoglossicida IsA and P. fluorescens B01. 1,2-DO-1,2dioxygenase; 2,3-DO—2,3-dioxygenase; SS—sodium succinate; $\mathrm{Ph}$-phenol; DE—diphenyl ether; BDE—4monobromodiphenyl ether; $\mathrm{CDE}-4$-monochlorodiphenyl ether. All measurements were made in triplicate and values are presented as mean \pm standard deviation.

\begin{tabular}{ccccc}
\hline \multirow{2}{*}{ Relative Enzymatic Activity $\left(\mathbf{m U ~ m g}^{-\mathbf{1}}\right)$} & \multicolumn{2}{c}{ P. plecoglossicida IsA } & \multicolumn{2}{c}{ P. fluorescens B01 } \\
\cline { 2 - 5 } & $\mathbf{1 , 2}$-DO & 2,3-DO & 1,2-DO & 2,3-DO \\
\hline SS & $277.72 \pm 13.89$ & $268.63 \pm 13.43$ & $0.01 \pm 0.00$ & $19.26 \pm 0.96$ \\
Ph & $127.10 \pm 6.35$ & $119.59 \pm 5.98$ & $0.05 \pm 0.02$ & $19.90 \pm 0.99$ \\
DE & $255.28 \pm 12.76$ & $110.64 \pm 5.53$ & $0.02 \pm 0.01$ & $12.44 \pm 0.62$ \\
DE + Ph & $0.66 \pm 0.03$ & $0.09 \pm 0.02$ & $494.50 \pm 24.72$ & $26.22 \pm 1.31$ \\
BDE & $83.28 \pm 4.16$ & $49.22 \pm 2.46$ & $8.47 \pm 0.42$ & $0.01 \pm 0.00$ \\
BDE + Ph & $339.27 \pm 16.96$ & $157.05 \pm 7.58$ & $126.71 \pm 6.34$ & $0.07 \pm 0.03$ \\
CDE & $0.08 \pm 0.02$ & $0.07 \pm 0.02$ & $2.11 \pm 0.11$ & $0.85 \pm 0.04$ \\
CDE + Ph & $2.19 \pm 0.11$ & $0.02 \pm 0.00$ & $237.70 \pm 11.89$ & $0.02 \pm 0.01$ \\
\hline
\end{tabular}

Similar to P. plecoglossicida IsA, the P. fluorescens B01 strain had higher activity of 1,2-dioxygenase than of 2,3-dioxygenase (Table 1). The highest activity of 1,2-dioxygenase was measured in the microbial cells grown in the co-metabolic conditions: $494.50 \pm 24.72 \mathrm{mU} \mathrm{mg}^{-1}$ for sample DE $+\mathrm{Ph}$, $237.70 \pm 11.89$ for CDE $+\mathrm{Ph}$, and $126.71 \pm 6.34$ for BDE $+\mathrm{Ph}$. Different results were observed for 2,3-dioxygenases. The enzymatic activity in the cultures with 4-monohalogenated diphenyl ethers was lower in co-metabolic conditions than in one-substrate conditions. On the other hand, in cultures with non-substituted diphenyl ether an increase in the activity of this enzyme was noted.

Catechol is an important intermediate in the degradation of phenol and similar compounds, mediating ring cleavage. The enzymes 1,2- and 2,3-dioxygenases are involved in this process from the very beginning, determining whether degradation will follow the meta or ortho cleavage pathway [35]. The presence of halogen substituents in degraded compounds can significantly decrease the relative activity of these enzymes, thus affecting biodegradation efficiency. Nowak and Mrozik have reported that the presence of phenol as a co-substrate inhibited 4-chlorophenol removal from soil [36]. This observation supports our results obtained for P. plecoglossicida IsA in the process of biodegradation of $\mathrm{DE}$ and $\mathrm{CDE}$ in the presence of phenol. Moreover, inhibition of 2,3-DO for both strains studied in the presence of CDE has also been noted by Wojcieszyńska et al. [37]. Similarly, negligible activity of 1,2-DO has been reported by Guzik et al. [38] when analyzing Stenotrophomonas maltophilia in monocyclic hydrocarbons degradation, as in the results presented for $P$. fluorescens B01. What is more, the very low 1,2-DO and 2,3-DO relative activity observed for this strain when single carbon sources were used might be correlated with the activation of different enzymes and degradation pathways. A similar observation was made by Wang et al. [39] during the biodegradation of aromatic compounds by Cupriavidus sp. WS. On the other hand, increased activity of 1,2-DO in P. fluorescens B01 in the presence of a co-metabolite has also been presented by Solyanikova et al. [40] in chlorophenol degradation studies. The high activity of this enzyme suggests further degradation of diphenyl ether derivatives in the presence of phenol by ortho cleavage pathway. The results of 1-2-DO and 2,3-DO relative activity suggest that the addition of a co-metabolite activates different enzymatic pathways than those active when a single carbon source was used. Moreover, the higher activity of catechol 1,2-dioxygenase in the co-metabolic systems indicates further degradation of the analyzed compounds by the ortho cleavage 
pathway. It should not be forgotten that the degradation of hydrocarbons is a complex process and other enzymes, such as dehydrogenases, oxidoreductases, and hydrolases, are also involved.

\subsection{Cell Membrane Permeability and Surface Hydrophobicity}

Bacterial cell surface hydrophobicity (CSH) and membrane permeability (MP) have been reported to be important parameters regulating microorganisms adhesion to hydrophobic substrates $[41,42]$. In this study, these features of the cells were examined on a single diphenyl ether derivative (DE, BDE or $\mathrm{CDE})$ or with phenol $(+\mathrm{Ph})$ addition as a co-substrate. The results presented in Table 2 reveal some interesting modifications of the cell hydrophobicity and membrane permeability depending on the carbon source in the culture.

Table 2. Results of membrane permeability and cell surface hydrophobicity of P. plecoglossicida IsA and P. fluorescens B01.

\begin{tabular}{|c|c|c|c|c|c|c|c|}
\hline & & DE & $\mathrm{DE}+\mathrm{Ph}$ & BDE & $\mathrm{BDE}+\mathrm{Ph}$ & CDE & $\mathrm{CDE}+\mathrm{Ph}$ \\
\hline \multirow{2}{*}{ P. plecoglossicida IsA } & $\mathbf{M P}(\mu \mathrm{mol} \mathrm{L}-1 \cdot \min )$ & $51.0 \pm 2.6$ & $46.0 \pm 2.3$ & $53.0 \pm 2.7$ & $49.0 \pm 2.5$ & $54.0 \pm 2.7$ & $51.0 \pm 2.6$ \\
\hline & CSH $(\%)$ & $27.0 \pm 1.4$ & $31.0 \pm 1.6$ & $65.0 \pm 3.3$ & $36.0 \pm 1.8$ & $54.0 \pm 2.7$ & $54.0 \pm 2.5$ \\
\hline \multirow{2}{*}{ P. fluorescens B01 } & $\mathbf{M P}(\mu \mathrm{mol} \mathrm{L}-1 \cdot \min )$ & $34.0 \pm 1.7$ & $45.0 \pm 2.3$ & $33.0 \pm 1.7$ & $37.0 \pm 1.9$ & $45.0 \pm 2.3$ & $54.0 \pm 2.7$ \\
\hline & $\operatorname{CSH}(\%)$ & $44.0 \pm 2.2$ & $51.0 \pm 2.6$ & $56.0 \pm 2.8$ & $30.0 \pm 1.5$ & $6.0 \pm 0.3$ & $16.0 \pm 0.8$ \\
\hline
\end{tabular}

For both strains, phenol addition caused changes in the investigated parameters; the changes in $\mathrm{CSH}$ were greater than those in membrane permeability. Moreover, MP changes in P. fluorescens B01 were greater than those observed for P. plecoglossicida IsA. The membrane permeability of P. plecoglossicida IsA decreased with phenol supplementation, regardless of the primary carbon source. In contrast, the membrane permeability of $P$. fluorescens B01 increased in response to phenol addition, although, similar to for P. plecoglossicida IsA, this rise was irrespective of the primary carbon source in the culture. These results illustrate that microbial strains can respond differently to identical changes in culture conditions. As the cell membrane is a barrier that prevents cells from direct contact with hydrophobic contaminants, the membrane permeability is crucial for effective compound transport inside the cell. The small decrease in cell membrane permeability observed for P. plecoglossicida IsA upon addition of phenol might be a result of phenol interaction with the membrane lipids. Hao et al. [43] have proven that co-metabolism of phenol and 4-chlorophenol allows the use of energy from phenol degradation for transformation of its more complex, chlorinated derivative. Considering also the specific plasmid-encoded hydrocarbon degradation pathway described for the P. plecoglossicida IsA strain by Marqués and Ramos [44], the addition of phenol might counterweight the negative effect of diphenyl ether on the membrane, thus slightly reducing the lipid bilayer permeability. In contrast, we observed an increase in P. fluorescens B01 membrane permeability, which might result from oxidative stress, as reported in [45]. Also, phenol addition might elicit efflux of potassium ions from the membrane, as in the case of E. coli [46], thus accelerating membrane permeability. Furthermore, the effect of phenol co-metabolism might be lower than for P. plecoglossicida IsA because of a different hydrocarbon metabolism pathway in this strain.

The second important parameter influencing the cell's ability to degrade hydrophobic compounds is the cell surface hydrophobicity. This parameter was investigated using the MATH method. According to the obtained results, the addition of phenol as a co-substrate to the cultures causes statistically significant changes in the cell surface hydrophobicity of $P$. fluorescens B01. In the case of the P. plecoglossicida IsA strain, only in cultures with BDE was an impact of phenol on CSH observed. Considering the differences in MP caused by phenol addition, statistically significant changes for DE and CDE were noticed. Moreover, in both cases the greatest decrease was noted when phenol was added to the cells grown on 4-bromodiphenyl ether (reduction by $29 \%$ and $26 \%$ for P. plecoglossicida IsA and P. fluorescens B01, respectively) resulting in both cases in a change in the membrane profile from hydrophobic to hydrophilic. The observed drop in hydrophobicity of the cells after phenol addition might be a result of microbial preference to use a more easily biodegradable substrate than highly 
hydrophobic brominated diphenyl ethers of low bioavailability [42]. When other carbon sources were present, phenol addition mostly caused an increase in CSH, regardless of the cells' surface being primarily hydrophobic or hydrophilic, but the observed changes were smaller for P. plecoglossicida IsA. Chen et al. [47] have demonstrated that Sphingobium hydrophobicum C1 cells with high cell surface hydrophobicity exposed to deca-bromophenyl ether remained hydrophobic, while the hydrophilic Sphingobium hydrophobicum $\mathrm{C} 2$ remained hydrophilic.

\section{Materials and Methods}

\subsection{Chemicals}

Fine chemicals, e.g., diphenyl ether, 4-bromodiphenyl ether, 4-chlorodiphenyl ether, phenol, 3-(4,5-dimethylthiazol-2-yl)-2,5-diphenyltetrazolium bromide, applied in the experiments were of the highest purity grade. They were purchased from Sigma-Aldrich (Poznan, Poland). For preparing all media and aqueous solutions, ultra-purified water (Arium ${ }^{\circledR}$ Pro, Sartorius, Kostrzyn Wlkp., Poland) was used.

\subsection{Preparation of Bacterial Suspensions and Their Treatment}

The bacterial strains used in our study were isolated from soil samples that were collected aseptically from an urbanized area in Greater Poland $\left(52^{\circ} 22^{\prime} 6^{\prime \prime} \mathrm{N}, 16^{\circ} 59^{\prime} 27^{\prime \prime}\right.$ E). Microbial strains were isolated with the use of the culture enrichment method. The enrichment culture contained soil samples, mineral salt medium (MSM) (composition $\left[g \mathrm{~L}^{-1}\right]$ : $\mathrm{Na}_{2} \mathrm{HPO}_{4} \cdot 2 \mathrm{H}_{2} \mathrm{O} 7.0, \mathrm{KH}_{2} \mathrm{PO}_{4} 2.8$, $\left.\mathrm{NaCl} 0.5, \mathrm{NH}_{4} \mathrm{Cl} 1.0\right)$ with the addition of sodium succinate and trace elements $\left(\mathrm{MgSO}_{4} \cdot 7 \mathrm{H}_{2} \mathrm{O} 0.35\right.$, $\mathrm{FeSO}_{4} \cdot 7 \mathrm{H}_{2} \mathrm{O} 0.035, \mathrm{CuSO}_{4} \cdot 7 \mathrm{H}_{2} \mathrm{O} 0.2, \mathrm{MnSO}_{4} \cdot 5 \mathrm{H}_{2} \mathrm{O} 0.2, \mathrm{ZnCl}_{2} 0.105, \mathrm{CoSO}_{4} \cdot 7 \mathrm{H}_{2} \mathrm{O} 0.025, \mathrm{H}_{3} \mathrm{BO}_{3} 0.285$ ) and hydrocarbons being the subject of the paper (DE, 4-BDE and 4-CDE) as the selective sources of carbon. The isolation process lasted eight weeks, and every seven days the microorganisms were transferred to a fresh culture medium to provide fresh nutrients. Each culture contained $45 \mathrm{~mL}$ mineral salt medium with the addition of trace elements and sodium succinate, $5 \mathrm{~mL}$ of the previous culture, and $0.05 \mathrm{~mL}$ of a (4-monohalogenated) diphenyl ethers solution. The liquid cultures were incubated at $30{ }^{\circ} \mathrm{C}$ with shaking at $120 \mathrm{rpm}$. After eight weeks microbes were cultured onto solid media, pure bacterial cultures were separated, and afterwards they were identified as Pseudomonas plecoglossicida IsA (IsA) and Pseudomonas fluorescens B01 (B01) according to their genetic properties with the use of $16 \mathrm{~S}$ rRNA gene amplification [48]. The nucleotide sequences of isolated bacteria are available in GenBank database under the accession numbers KY561350 (IsA) and KY557338 (B01).

The microorganisms were stored in standard general-purpose solid media. In order to establish the liquid cultures, the MSM was inoculated with one loop of bacteria taken from an agar plate. It was cultivated at $30^{\circ} \mathrm{C}$ for $48 \mathrm{~h}$.

Afterwards, the bacterial suspensions were centrifuged at $4000 \times g$ for $10 \mathrm{~min}$, then the supernatant was discarded, and the cell pellets were washed three times with sterile MSM. The bacterial cell suspensions were prepared by resuspending the cell pellet in autoclaved MSM to reach a final bacteria concentration of $1 \times 10^{9} \mathrm{cfu} \mathrm{mL}^{-1}$ (mid log phase; optical density $\left(\mathrm{OD}_{600}\right) 1.0$ at $\lambda=600 \mathrm{~nm}$ ).

The liquid bacterial cultures for the subsequent experiments were started by adding $5 \mathrm{~mL}$ bacterial inoculum, $45 \mathrm{~mL}$ sterile MSM with microelements and the filter-sterilized acetone solution (100 $\mathrm{mg} \mathrm{mL}^{-1}$ ) of diphenyl ether, 4-bromodiphenyl ether, or 4-chlorodiphenyl ether and phenol to sterile 250-mL Duran ${ }^{\circledR}$ Schott laboratory glass bottles. The final concentration of ethers and/or phenol in each sample was $40 \mathrm{mg} \mathrm{L}^{-1}$.

\subsection{Biodegradation}

Biodegradation of diphenyl ether and its 4-monohalogenated derivatives by Pseudomonas plecoglossicida IsA and Pseudomonas fluorescens B01 was determined in the one-substrate and co-metabolic systems (phenol was used as a co-metabolic substrate). The liquid cultures were incubated 
at $30{ }^{\circ} \mathrm{C}$ with shaking at $120 \mathrm{rpm}$. The analysis was performed in 7-, 14-, and 21-day cultures. After that time, $10 \mathrm{~mL}$ of hexane and internal standard (4-chlorodiphenyl ether in cultures containing 4-bromodiphenyl ether or diphenyl ether, diphenyl ether in cultures containing 4-chlorodiphenyl ether) were added to the cultures in bottles.

The concentration of residual diphenyl ether or its 4-monohalogenated derivatives was determined using a gas chromatography-mass spectrometry instrument Pegasus 4D GCxGC-TOMF/MS (LECO, St. Joseph, MI, USA). The compounds mentioned were determined on the BPX-5 (28m, $250 \mu \mathrm{m}$, $0.25 \mu \mathrm{m}$ ) column from SGE Analytical Science, (Ringwood, Australia) with helium as a carrier gas. The dosage temperature was $250{ }^{\circ} \mathrm{C}$. During the first minute of analysis the temperature was $40{ }^{\circ} \mathrm{C}$. Then, the programmed temperature gradient was applied $\left(15^{\circ} \mathrm{C} \mathrm{min}^{-1}\right.$ up to $180^{\circ} \mathrm{C}$, next $10^{\circ} \mathrm{C} \mathrm{min}^{-1}$ up to $250^{\circ} \mathrm{C}$; the final temperature was maintained for three minutes). The whole analysis lasted $20 \mathrm{~min}$ and $20 \mathrm{~s}$. The eluate from the column was directed to the mass spectrometer through the electron ionization source working in the positive ionization mode. The temperature of the ion source was $250^{\circ} \mathrm{C}$ and the electron energy was $70 \mathrm{~V}$. The quantitative analysis was performed for the ion signal at $141 \mathrm{~m} / \mathrm{z}$. The contents of the compounds analyzed in the samples were determined according to a calibration curve that was based on the measurement of analogous samples with known diphenyl ether concentration.

The content of the remaining phenol was determined with the use of HPLC/FD from Dionex (Sunnyvale, CA, USA) consisting of a P580 A LPG gradient pump, an ASI-100 autosampler, an STH 585 oven and an RF 2000 fluorescence detector. Exactly $5 \mu \mathrm{L}$ samples were injected into a C18 Hypersil GOLD column $(150 \mathrm{~mm} ; 4.6 \mathrm{~mm}$ I.D.; $5 \mu \mathrm{m})$ with a $2.1 \mathrm{~mm}$ I.D. filter cartridge $(0.2 \mu \mathrm{m})$ from Thermo Scientific (Waltham, MA, USA). The mobile phase consisted of solvent A ( $20 \%$ methanol) and solvent

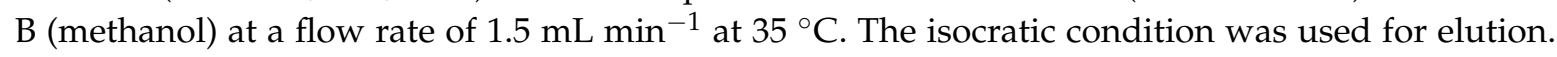
The mobile phase consisted of $40 \%$ B. Signal responses were measured by fluorescence detection at wavelengths set at $272 \mathrm{~nm}$ for excitation and $305 \mathrm{~nm}$ for emission. The linearity of the method was tested in a wide range. The instrumental limit of detection (LOD) and the instrumental limit of quantitation (LOQ) were calculated on the basis of the signal to noise $(\mathrm{S} / \mathrm{N})$ ratio. $\mathrm{S} / \mathrm{N}=3$ was used for calculation of LOD and S/N = 10 for calculation of LOQ. Precision and accuracy were not tested because sample preparation included only a dilution step. Therefore, only injection precision of the instrument applies in this procedure; it was always below 1\% (LOD $1.8 \mu \mathrm{g} \mathrm{L}^{-1}$; LOQ $6.0 \mu \mathrm{g} \mathrm{L}^{-1}$; linear range $\left.10-2000 \mu \mathrm{g} \mathrm{L}^{-1}\right)$.

\subsection{Cells' Metabolic Activity}

Evaluation of total cell metabolic activity during (4-monohalogenated) diphenyl ether biodegradation in both one-substrate systems and co-metabolic ones was also performed in this study. The analysis was performed at the start of the biodegradation and then on the 7th and 14th days of the process. The metabolic activities obtained in further experiments were calculated as a percentage of the initial value for each sample.

The assay was performed according to the modified method described in [49]. In the study the reaction mixture volume was $1 \mathrm{~mL}$. The samples contained $0.9 \mathrm{~mL}$ of microbial culture, which was prepared in the same manner as the culture for biodegradation tests. The bacteria were incubated with $0.1 \mathrm{~mL} 5 \mathrm{~g} \mathrm{~L}^{-1}$ MTT (3-(4,5-dimethylthiazol-2-yl)-2,5-diphenyltetrazolium bromide) solution (the final concentration of MTT in the samples was $0.5 \mathrm{~g} \mathrm{~L}^{-1}$ ) for $2 \mathrm{~h}$ at $30^{\circ} \mathrm{C}$ in the dark. After incubation, the cultures were centrifuged at $15,000 \times \mathrm{g}$. Then, $1 \mathrm{~mL}$ of propan-2-ol was added to the cells in order to dissolve the formazan precipitate formed by metabolically active microbial cells. Afterwards, the samples were centrifuged one more time at $4000 \times g$ and the absorbance of supernatant was analyzed on a UV-Vis spectrophotometer (Jasco, Tokyo, Japan) at $560 \mathrm{~nm}$. Each measurement was repeated three times. 


\subsection{Crude Extract Preparation and Enzyme Activity Evaluation}

Cell suspensions prepared according to the method described above, after seven days of incubation, were harvested at $4000 \times \mathrm{g}$ for $10 \mathrm{~min}$, washed twice with $10 \mathrm{mM}$ sterile potassium phosphate buffer ( $\mathrm{pH} 7.0$ ), sonicated (six times for $15 \mathrm{~s}$ at $30 \mathrm{~s}$ intervals, frequency $20 \mathrm{kHz}$, samples kept on ice), and centrifuged again at $20,000 \times g$ for $20 \mathrm{~min}$ at $4{ }^{\circ} \mathrm{C}$. The supernatant obtained, incubated on ice during the analysis, was used for the total protein determination and enzyme assays.

Protein content of the sonicated suspensions was determined by the Bradford procedure [50], using Probumin ${ }^{\circledR}$ (Merck, Warsaw, Poland) as a standard.

Catechol 1,2-dioxygenase (1,2-DO) and catechol 2,3-dioxygenase (2,3-DO) activity was assayed according to the methodology described by Singh et al. [35]. Briefly, 20- $\mu \mathrm{L}$ samples containing $0.08-0.24 \mathrm{mg}$ of protein were added to the reaction mixture containing $20 \mu \mathrm{L} 0.1 \mu \mathrm{mol} \mathrm{mL}^{-1}$ catechol and $960 \mu \mathrm{L} 10 \mathrm{mM}$ potassium phosphate buffer. The sample prepared for the determination of catechol 1,2-dioxygenase also contained $1.0 \mu \mathrm{mol} \mathrm{mL}^{-1}$ of EDTA. The total reaction mixture volume was $4 \mathrm{~mL}$. To determine the activity of 1,2-DO, the formation of cis,cis-muconate was measured spectrophotometrically $(\lambda=260 \mathrm{~nm})$; however, for 2,3-DO, the formation of 2-hydroxymuconic semialdehyde was monitored at $375 \mathrm{~nm}$. The enzymatic activity of 1,2-DO and 2,3-DO obtained was divided by the total protein content of the crude cell extract in order to get the specific enzyme activity (U per mg of protein).

\subsection{Membrane Permeability}

The changes in membrane permeability caused by the presence of diphenyl ethers and/or phenol in the culture were evaluated by crystal violet (CV) assay, described in [51], with some modifications. Bacterial cell suspensions were harvested at $4000 \times g$ for $10 \mathrm{~min}$ at $4{ }^{\circ} \mathrm{C}$ and washed twice with a mineral salt medium. Then they were incubated at $30^{\circ} \mathrm{C}$ for seven days in one-substrate systems with diphenyl ether, 4-chlorodiphenylether, or 4-bromodiphenyl ether as well as in two-substrate systems that contained $10 \mathrm{mg} \mathrm{L}^{-1}$ of phenol as a co-metabolite. Control samples were prepared similarly but did not contain microorganisms.

After incubation, the cells were harvested and resuspended in MSM to reach $\mathrm{OD}_{600}$ 0.9-1.0. Afterwards, $0.95 \mathrm{~mL}$ of cultures and $0.05 \mathrm{~mL}$ of crystal violet solution $\left(0.1 \mathrm{mgmL}^{-1}\right)$ were added to microcentrifuge tubes. After incubating at $30^{\circ} \mathrm{C}$ for $10 \mathrm{~min}$, the suspension was centrifuged at $13,400 \times g$ for $15 \mathrm{~min}$ and the absorbance of the supernatant was measured at $590 \mathrm{~nm}\left(\mathrm{~A}_{590 \_\mathrm{S}}\right)$. The absorbance value of the pure crystal violet solution $\left(\mathrm{A}_{590 \_\mathrm{CV}}\right)$ was considered as $100 \%$. The percentage of crystal violet uptake was expressed according to Equation (1):

$$
\text { \%uptake of } C V=\frac{A_{590 \_C V}-A_{590 \_S}}{A_{590 \_C V}} \times 100 \%
$$

\subsection{Cell Surface Hydrophobicity}

The impact of the presence of diphenyl ethers and/or phenol on cell surface hydrophobicity modifications was evaluated using Congo Red (CR) assay described in [23] after some modifications. Bacteria cell suspensions were prepared in the same manner as for membrane permeability evaluation. After seven days of incubation at $30^{\circ} \mathrm{C}$, the cells were harvested and resuspended in MSM to reach $\mathrm{OD}_{600}$ 0.9-1.0. Afterwards, $0.9 \mathrm{~mL}$ of cultures and $0.1 \mathrm{~mL}$ of Congo Red solution $\left(1 \mathrm{mg} \mathrm{mL}^{-1}\right)$ were introduced to microcentrifuge tubes. After incubating at $30^{\circ} \mathrm{C}$ for $10 \mathrm{~min}$, the suspension was centrifuged at $9000 \times g$ for $30 \mathrm{~min}$ and the absorbance of the supernatant was measured at $480 \mathrm{~nm}$ $\left(\mathrm{A}_{480 \_\mathrm{S}}\right)$. The absorbance value of pure Congo Red solution $\left(\mathrm{A}_{480} \mathrm{CR}\right)$ was considered as $100 \%$. The cell surface hydrophobicity was expressed according to Equation (2):

$$
\% \text { hydrophobicity }=\frac{\mathrm{A}_{480 \_} \mathrm{CR}-\mathrm{A}_{480 \_} \mathrm{S}}{\mathrm{A}_{480} \mathrm{CR}} \times 100 \%
$$




\section{Conclusions}

The tested bacteria strains exhibited high biodegradability potential. What is more, 4-monohalogenated diphenyl ethers were found to be more degradable than their unsubstituted equivalents. The highest degree of degradation of the contaminants studied was noted in the sample containing chlorinated diphenyl ethers, phenol, and P. fluorescens B01. The activity of enzymes taking place in the degradation process was higher in the cultures grown in co-metabolic conditions. Moreover, the higher activity of catechol 1,2-dioxygenase in co-metabolic systems indicates further degradation of the analyzed compounds by an ortho cleavage pathway. The degradation of 4-monohalogenated derivatives of diphenyl ether was more effective in the co-metabolic systems. This suggests that biodegradation in a co-metabolic system with phenol can be a useful strategy for the bioremediation of soil contaminated with diphenyl ether and its derivatives.

Author Contributions: Conceptualization, A.P. and W.S.; Investigation, A.P., W.S., A.Z. and A.Z.-G.; WritingOriginal Draft Preparation, A.P., W.S., A.Z. and A.Z.-G.; Writing-Review \& Editing, E.K.; Visualization, A.P., A.Z.; Supervision, E.K.

Funding: This research was funded by Poznan University of Technology through the research grant No. 03/32/DSMK/0816.

Conflicts of Interest: The authors declare no conflict of interest. The funders had no role in the design of the study; in the collection, analyses, or interpretation of data; in the writing of the manuscript, or in the decision to publish the results.

\section{References}

1. Yu, H.; Yang, H.; Cui, D.; Lv, L.; Li, B. Synthesis and herbicidal activity of diphenyl ether derivatives containing unsaturated carboxylates. J. Agric. Food Chem. 2011, 59, 11718-11726. [CrossRef] [PubMed]

2. McGrath, T.J.; Ball, A.S.; Clarke, B.O. Critical review of soil contamination by polybrominated diphenyl ethers (PBDEs) and novel brominated flame retardants (NBFRs); concentrations, sources and congener profiles. Environ. Pollut. 2015, 230, 741-757. [CrossRef] [PubMed]

3. Qin, L.; Feng, M.; Zhang, X.; Wang, L.; Wang, Z. Occurrence of polychlorinated diphenyl ethers in Nanjing section of the Yangtze River: Level and distribution pattern. Environ. Sci. Pollut. Res. 2015, 22, 9224-9232. [CrossRef] [PubMed]

4. Sjödin, A.; Patterson, D.G.; Bergman Åke, Å. A review on human exposure to brominated flame retardantsParticularly polybrominated diphenyl ethers. Environ. Int. 2003, 29, 829-839. [CrossRef]

5. Kelly, B.C.; Ikonomou, M.G.; Blair, J.D.; Gobas, F.A. Bioaccumulation behaviour of polybrominated diphenyl ethers (PBDEs) in a Canadian Arctic marine food web. Sci. Total Environ. 2008, 401, 60-72. [CrossRef] [PubMed]

6. Siddiqi, M.A.; Laessig, R.H.; Reed, K.D. Polybrominated diphenyl ethers (PBDEs): New pollutants-old diseases. Clin. Med. Res. 2003, 1, 281-290. [CrossRef] [PubMed]

7. Koistinen, H.; Koistinen, R.; Dell, A.; Morris, H.R.; Easton, R.L.; Patankar, M.S.; Oehninger, S.; Clark, G.F.; Seppälä, M. Glycodelin from seminal plasma is a differentially glycosylated form of contraceptive glycodelin-A. Mol. Hum. Reprod. 1996, 2, 759-765. [CrossRef] [PubMed]

8. Domingo, J.L. Polychlorinated diphenyl ethers (PCDEs): Environmental levels, toxicity and human exposure: A review of the published literature. Environ. Int. 2006, 32, 121-127. [CrossRef] [PubMed]

9. Mrozik, A.; Piotrowska-Seget, Z.; Łabużek, S. Bacteria in bioremediation of hydrocarbon-contaminated environment. Postępy Mikrobiol. 2005, 44, 227-238.

10. Hiraishi, A. Biodiversity of dioxin-degrading microorganisms and potential utilization in bioremediation. Microbes Environ. 2014, 18, 105-125. [CrossRef]

11. Lv, Y.; Li, L.; Chen, Y.; Tang, Z.; Hu, Y. Effects of glucose and biphenyl on aerobic cometabolism of polybrominated diphenyl ethers by Pseudomonas putida: Kinetics and degradation mechanism. Int. Biodeterior. Biodegrad. 2016, 108, 76-84. [CrossRef] 
12. Seo, J.S.; Keum, Y.S.; Li, Q.X. Bacterial Degradation of Aromatic Compounds. Int. J. Environ. Res. Public Health 2009, 6, 278-309. [CrossRef]

13. Dvořák, P.; Nikel, P.I.; Damborský, J.; de Lorenzo, V. Bioremediation 3.0: Engineering pollutant-removing bacteria in the times of systemic biology. Biotechnol. Adv. 2017, 35, 845-866. [CrossRef] [PubMed]

14. Li, Y.; Li, B.; Wang, C.P.; Fan, J.Z.; Sun, H.W. Aerobic degradation of trichloroethylene by co-metabolism using phenol and gasoline as growth substrates. Int. J. Mol. Sci. 2014, 15, 9134-9148. [CrossRef] [PubMed]

15. Domaradzka, D.; Guzik, U.; Hupert-Kocurek, K.; Wojcieszyńska, D. Cometabolic Degradation of Naproxen by Planococcus sp. Strain S5. Water. Air. Soil Pollut. 2015, 226, 297. [CrossRef] [PubMed]

16. Hedegaard, M.J.; Deliniere, H.; Prasse, C.; Dechesne, A.; Smets, B.F.; Albrechtsen, H.J. Evidence of co-metabolic bentazone transformation by methanotrophic enrichment from a groundwater-fed rapid sand filter. Water Res. 2018, 129, 105-114. [CrossRef] [PubMed]

17. Khodaei, K.; Nassery, H.R.; Asadi, M.M.; Mohammadzadeh, H.; Mahmoodlu, M.G. BTEX biodegradation in contaminated groundwater using a novel strain (Pseudomonas sp. BTEX-30). Int. Biodeterior. Biodegrad. 2017, 116, 234-242. [CrossRef]

18. Derakhshan, Z.; Mahvi, A.H.; Ehrampoush, M.H.; Mazloomi, S.M.; Faramarzian, M.; Dehghani, M.; Yousefinejad, S.; Ghaneian, M.T.; Abtahi, S.M. Studies on influence of process parameters on simultaneous biodegradation of atrazine and nutrients in aquatic environments by a membrane photobioreactor. Environ. Res. 2018, 161, 599-608. [CrossRef] [PubMed]

19. Tang, K.; Escola Casas, M.; Ooi, G.T.H.; Kaarsholm, K.M.S.; Bester, K.; Andersen, H.R. Influence of humic acid addition on the degradation of pharmaceuticals by biofilms in effluent wastewater. Int. J. Hyg. Environ. Health 2017, 220, 604-610. [CrossRef] [PubMed]

20. Baggi, G.; Bernasconi, S.; Zangrossi, M. 3-Chloro-, 2,3- and 3,5-dichlorobenzoate co-metabolism in a 2-chlorobenzoate-degrading consortium: Role of 3,5-dichlorobenzoate as antagonist of 2-chlorobenzoate degradation-Metabolism and co-metabolism of chlorobenzoates. Biodegradation 2005, 16, $275-282$. [CrossRef] [PubMed]

21. Priya, V.S.; Philip, L. Biodegradation of dichloromethane along with other VOCs from pharmaceutical wastewater. Appl. Biochem. Biotechnol. 2013, 169, 1197-1218. [CrossRef] [PubMed]

22. Zhang, Y.; Tay, J.H. Toxic and inhibitory effects of trichloroethylene aerobic co-metabolism on phenol-grown aerobic granules. J. Hazard. Mater. 2015, 286, 204-210. [CrossRef] [PubMed]

23. Mamma, D.; Kalogeris, E.; Papadopoulos, N.; Hatzinikolaou, D.G.; Christrakopoulos, P.; Kekos, D. Biodegradation of phenol by acclimatized Pseudomonas putida cells using glucose as an added growth substrate. J. Environ. Sci. Health. A. Tox. Hazard. Subst. Environ. Eng. 2004, 39, 2093-2104. [CrossRef] [PubMed]

24. Bakhshi, Z.; Najafpour, G.; Kariminezhad, E.; Pishgar, R.; Mousavi, N.; Taghizade, T. Growth kinetic models for phenol biodegradation in a batch culture of Pseudomonas putida. Environ. Technol. 2011, 33, 1835-1841. [CrossRef] [PubMed]

25. Perpetuo, E.A.; Silva, D.N.; Avanzi, I.R.; Gracioso, L.H.; Baltazar, M.P.G.; Nascimento, C.A.O. Phenol biodegradation by a microbial consortium: Application of artificial neural network (ANN) modelling. Environ. Technol. 2012, 33, 1739-1745. [CrossRef] [PubMed]

26. Kim, Y.-M.; Nam, I.-H.; Murugesan, K.; Schmidt, S.; Crowley, D.E.; Chang, Y.-S. Biodegradation of diphenyl ether and transformation of selected brominated congeners by Sphingomonas sp. PH-07. Appl. Microbiol. Biotechnol. 2007, 77, 187-194. [CrossRef] [PubMed]

27. Wu, Z.; Xie, M.; Li, Y.; Gao, G.; Bartlam, M.; Wang, Y. Biodegradation of decabromodiphenyl ether (BDE 209) by a newly isolated bacterium from an e-waste recycling area. AMB Express 2018, 8, 27. [CrossRef] [PubMed]

28. Heidari, H.; Sedighi, M.; Zamir, S.M.; Shojaosadati, S.A. Bisphenol A degradation by Ralstonia eutropha in the absence and presence of phenol. Int. Biodeterior. Biodegradation 2017, 119, 37-42. [CrossRef]

29. Chen, C.-Y.; Wang, C.-K.; Shih, Y.-H. Microbial degradation of 4-monobrominated diphenyl ether in an aerobic sludge and the DGGE analysis of diversity. J. Environ. Sci. Heal. Part B 2010, 45, 379-385. [CrossRef] [PubMed]

30. Balamurugan, V.; Balakrishnan, V.; Philip Robinson, J.; Ramakrishnan, M. Anticancer and apoptosis-inducing effects of Moringa concanensis using hepG2 cell lines. Bangladesh J. Pharmacol. 2014, 9, 604-609. [CrossRef] 
31. Vollár, M.; Gyovai, A.; Szúcs, P.; Zupkó, I.; Marschall, M.; Csupor-Löffler, B.; Bérdi, P.; Vecsernyés, A.; Csorba, A.; Liktor-Busa, E.; et al. Antiproliferative and antimicrobial activities of selected bryophytes. Molecules 2018, 23, 1520. [CrossRef] [PubMed]

32. Xu, Y.; Sun, G.-D.; Jin, J.-H.; Liu, Y.; Luo, M.; Zhong, Z.-P.; Liu, Z.-P. Successful bioremediation of an aged and heavily contaminated soil using a microbial/plant combination strategy. J. Hazard. Mater. 2014, 264, 430-438. [CrossRef] [PubMed]

33. Scelza, R.; Antonietta Rao, M.; Gianfreda, L. Effects of compost and of bacterial cells on the decontamination and the chemical and biological properties of an agricultural soil artificially contaminated with phenanthrene. Soil Biol. Biochem. 2007, 39, 1303-1317. [CrossRef]

34. Xu, Y.; Lu, M. Bioremediation of crude oil-contaminated soil: Comparison of different biostimulation and bioaugmentation treatments. J. Hazard. Mater. 2010, 183, 395-401. [CrossRef] [PubMed]

35. Singh, S.N.; Kumari, B.; Upadhyay, S.K.; Mishra, S.; Kumar, D. Bacterial degradation of pyrene in minimal salt medium mediated by catechol dioxygenases: Enzyme purification and molecular size determination. Bioresour. Technol. 2013, 133, 293-300. [CrossRef] [PubMed]

36. Nowak, A.; Mrozik, A. Degradation of 4-chlorophenol and microbial diversity in soil inoculated with single Pseudomonas sp. CF600 and Stenotrophomonas maltophilia KB2. J. Environ. Manage. 2018, 215, $216-229$. [CrossRef] [PubMed]

37. Wojcieszyńska, D.; Hupert-Kocurek, K.; Guzik, U. Factors affecting activity of catechol 2,3-dioxygenase from 2-chlorophenol-degrading Stenotrophomonas maltophilia strain KB2. Biocatal. Biotransformation 2013, 31, 141-147. [CrossRef]

38. Guzik, U.; Greń, I.; Wojcieszyńska, D.; Łabużek, S. Isolation and characterization of a novel strain of Stenotrophomonas maltophilia possessing various dioxygenases for monocyclic hydrocarbon degradation. Brazilian J. Microbiol. 2009, 40, 285-291. [CrossRef]

39. Wang, S.; Bai, N.; Wang, B.; Feng, Z.; Hutchins, W.C.; Yang, C.-H.; Zhao, Y. Characterization of the molecular degradation mechanism of diphenyl ethers by Cupriavidus sp. WS. Environ. Sci. Pollut. Res. 2015, 22, 16914-16926. [CrossRef] [PubMed]

40. Solyanikova, I.P.; Golovleva, L.A. Bacterial degradation of chlorophenols: Pathways, biochemica, and genetic aspects. J. Environ. Sci. Health. B. 2004, 39, 333-351. [CrossRef] [PubMed]

41. Sikkema, J.; de Bont, J.A.; Poolman, B. Mechanisms of membrane toxicity of hydrocarbons. Microbiol. Rev. 1995, 59, 201-222. [PubMed]

42. Zhao, C.; Yan, M.; Zhong, H.; Liu, Z.; Shi, L.; Chen, M.; Zeng, G.; Song, B.; Shao, B.; Feng, H. Biodegradation of polybrominated diphenyl ethers and strategies for acceleration: A review. Int. Biodeterior. Biodegradation 2018, 129, 23-32. [CrossRef]

43. Hao, O.J.; Kim, M.H.; Seagren, E.A.; Kim, H. Kinetics of phenol and chlorophenol utilization by Acinetobacter species. Chemosphere 2002, 46, 797-807. [CrossRef]

44. Marqués, S.; Ramos, J.L. Transcriptional control of the Pseudomonas putida TOL plasmid catabolic pathways. Mol. Microbiol. 1993, 9, 923-929. [CrossRef] [PubMed]

45. Wang, L.; Tang, L.; Wang, R.; Wang, X.; Ye, J.; Long, Y. Biosorption and degradation of decabromodiphenyl ether by Brevibacillus brevis and the influence of decabromodiphenyl ether on cellular metabolic responses. Environ. Sci. Pollut. Res. 2016, 23, 5166-5178. [CrossRef] [PubMed]

46. Heipieper, H.J.; Keweloh, H.; Rehm, H.J. Influence of phenols on growth and membrane permeability of free and immobilized Escherichia coli. Appl. Environ. Microbiol. 1991, 57, 1213-1217. [PubMed]

47. Chen, X.; Song, D.; Xu, J.; Li, E.; Sun, G.; Xu, M. Role and mechanism of cell-surface hydrophobicity in the adaptation of Sphingobium hydrophobicum to electronic-waste contaminated sediment. Appl. Microbiol. Biotechnol. 2018, 102, 2803-2815. [CrossRef] [PubMed]

48. Kaczorek, E.; Sałek, K.; Guzik, U.; Dudzińska-Bajorek, B. Cell surface properties and fatty acids composition of Stenotrophomonas maltophilia under the influence of hydrophobic compounds and surfactants. New Biotechnol. 2013, 30, 173-182. [CrossRef] [PubMed]

49. Jafarirad, S.; Mehrabi, M.; Divband, B.; Kosari-Nasab, M. Biofabrication of zinc oxide nanoparticles using fruit extract of Rosa canina and their toxic potential against bacteria: A mechanistic approach. Mater. Sci. Eng. C 2016, 59, 296-302. [CrossRef] [PubMed] 
50. Bradford, M.M. A rapid and sensitive method for the quantitation of microgram quantities of protein utilizing the principle of protein-dye binding. Anal. Biochem. 1976, 72, 248-254. [CrossRef]

51. Devi, K.P.; Sakthivel, R.; Nisha, S.A.; Suganthy, N.; Pandian, S.K. Eugenol alters the integrity of cell membrane and acts against the nosocomial pathogen Proteus mirabilis. Arch. Pharm. Res. 2013, 36, 282-292. [CrossRef] [PubMed] 